\title{
ANALISIS HUKUM TATA NEGARA: SISTEM PENETAPAN GUBERNUR KEPALA DAERAH ISTIMEWA YOGYAKARTA DALAM SISTEM PEMILIHAN KEPALA DAERAH BERDASARKAN PASAL 18 AYAT (4) UUD 1945
}

\author{
Titik Triwulan Tutik ${ }^{1}$
}

\begin{abstract}
Administration privileges in an area basically refers to: (1) the historical value, (2) genekologis values, (3) socio-cultural values, as well as juridical value. Yogyakarta, both historically and juridically have strong legitimacy as a special area. Historically, First, the status of the privilege of Yogyakarta is a conscious political choice taken by the ruler of Yogyakarta, Sultan HB IX and Paku Alam VIII, and not the administration of the national political entities. Second, the Yogyakarta area and provide space for the residents of Indonesia early concrete. Third, Yogyakarta became the savior when Indonesian forces in crisis situations to maintain the Declaration of Independence August 17, 1945. While legally the First, the consistency in the judicial level that recognizes the existence of a special regions. Second, the consistency of recognition of the privilege status of a region, not followed by a comprehensive arrangement of the substance of the privilege of an area. DIY Keistimwaan also reflected in the charging mechanism Guernur To the Regional office and the Deputy Governor, with the appointment system/establishment and Sri Sri Sultan Pakualam directly by the President. In the determination of the constitutional system Hamengkubuwono X and Sri Pakualam, as Governor and Deputy Governor of Yogyakarta is not contrary to the constitution (unconstitutional) for the determination of the gain legitimacy from the people (public wills).
\end{abstract}

Keywords: Priveleges of DIY, Determination System of the Governor of Yogyakarta, Regional Head Election Systems Based on the 1945

\begin{abstract}
Abstrak
Pemerintahan keistimewaan pada suatu daerah pada dasarnya merujuk pada: (1) nilai historis, (2) nilai-nilai genekologis; (3) nilai sosial-budaya, selain juga nilai yuridis. Daerah Istimewa Yogyakarta, baik secara historis maupun yuridis memiliki legitimasi yang kuat sebagai daerah istimewa. Secara historis, Pertama, status keistimewaan Yogyakarta merupakan pilihan politik sadar yang diambil penguasa Yogyakarta, yakni Sultan HB IX dan
\end{abstract}

${ }^{1}$ Titik Triwulan Tutik adalah Dosen Hukum Tata Negara Fakultas Syari'ah IAIN Sunan Ampel Surabaya. Alamat kontak penulis: tt titik@yahoo.com. 
Paku Alam VIII, dan bukan pemberian dari entitas politik nasional. Kedua, Yogyakarta memberikan ruang wilayah dan penduduk yang kongkrit bagi Indonesia awal. Ketiga, Yogyakarta menjadi kekuatan penyelamat ketika Indonesia berada dalam situasi krisis untuk mempertahankan Proklamasi Kemerdekaan 17 Agustus 1945. Sedangkan secara yuridis yaitu Pertama, adanya konsistensi pada level yuridis yang mengakui keberadaan suatu daerah yang bersifat istimewa. Kedua, konsistensi pengakuan atas status keistimewaan sebuah daerah, tidak diikuti oleh pengaturan yang bersifat komprehensif mengenai substansi keistimewaan sebuah daerah. Keistimwaan DIY juga tercermin dalam mekanisme pengisian jabatan Guernur Kepada Daerah dan Wakil Gubernur, dengan sistem pengangkatan/ penetapan Sri Sultan dan Sri Pakualam secara langsung oleh Presiden. Secara konstitusional sistem penetapan Hamengku Buwono X dan Sri Pakualam, sebagai Gubernur dan Wakil Gubernur DIY tidaklah bertentangan dengan konstitusi (inkonstitusional) selama penetapan tersebut memperoleh legitimasi dari masyarakat (masyarakat menghendakinya).

Kata Kunci: Keistimewaan DIY, Sistem Penetapan Gubernur Kepala Daerah DIY, Sistem Pemilihan Kepala Daerah Berdasarkan UUD 1945

\section{Pendahuluan}

Polemik keistimewaan Yogyakarta kembali menjadi wacana serius dalam sistem ketatanegaraan Indonesia. Pertanyaan muncul ketika eksistensi "sistem pemerintahan DIY yang bercorak monarkhi" dewasa ini dianggap kurang sesuai dengan "sistem demokrasi". Permasalahan ini muncul, ketika orang nomor satu di Indonesia Presiden SBY, dalam salah satu penjelasannya dalam sidang kabinet bidang politik, hukum dan keamanan tanggal 26 November 2010 mengelarkan statemen bahwa sistem monarki (yang berlaku DIY) dianggap sudah kurang sesuai lagi dengan semangat demokrasi yang kini sedang dilaksanakan di Indonesia.

Sebenarnya secara subtansial pernyataan Presiden membahas tentang posisi dasar pemerintah, berkaitan dengan Undang Undang tentang Keistimewaan Daerah Istimewa Yogyakarta atau tentang pemerintahan Daerah Istimewa Yogyakarta. Berkaitan dengan posisi tersebut terdapat 3 (tiga) esensi pokok, yaitu: Pertama, pilar keistimewaan DIY bertumpu pada sistem nasional yaitu Negara Kesatuan Republik Indonesia yang dalam Undang Undang Dasar sebagaimana telah diatur dengan gamblang termasuk dalam Pasal 18. Kedua, pemahaman keistimewaan Daerah Istimewa Yogyakarta harus merujuk pada bentangan sejarah, dan aspek-aspek lain yang memang harus diperlakukan secara khusus, sebagaimana pula yang diatur dalam Undang Undang Dasar serta harus nampak dalam struktur pemerintahan keistimewaan. Ketiga, mengingat NKRI adalah negara hukum dan negara demokrasi. Maka, nilai-nilai demokrasi, democratic values, tidak boleh diabaikan karena tentu 
tidak mungkin ada sistem monarki yang bertabrakan, baik dengan konstitusi maupun dengan nilai-nilai demokrasi. ${ }^{2}$

Berdasarkan pernyataan Presiden tersebut, pada dasarnya terdapat 3 (tiga) pilar yang mesti ditegakkan, dalam membangun dan merumuskan keistimewaan DIY, yaitu: (1) sistem nasional dan NKRI yang semuanya ada dalam UUD 1945; (2) keistimewaan Yogyakarta itu sendiri yang harus nyata dan ekplisit diwadahi, dan (3) implementasi dari nilai dan sistem demokrasi.

Akibat, dari pernyataan tersebut terdapat misunderstanding sehingga kawula ngarsa dalem Ngayogyakarto (masyarakat yogyakarta) angkat bicara. Mereka beranggapan, bahwa pemerintah (yang dalam hal Presiden SBY) telah melakukan intervensi terhadap keistimewaan DIY. SBY dianggap tidak memahami nilai-nilai keistimewaan DIY itu sendiri, baik dari sudut pandang histories, filosofis, maupun yuridis.

Menanggapi pernyataan Presiden tersebut, Hotman Siahaan berpendapat:

Keistimewaan Yogyakarta tidak patut dipertanyakan lagi. Pemerintah pusat juga tidak sepatutnya menyebut Keraton Yogyakarta sebagai bagian dari monarki. "Mereka yang mempertanyakan keistimewaan Yogyakarta tidak mengerti sejarah dan sumbangsih Yogyakarta. Sistem pemerintahan di Provinsi DIY bersifat monarki jelas salah alamat. Istilah monarki dalam konteks DIY hanyalah simbolisasi kultural Jawa, bukan monarki politik. Pemerintahan DIY menerapkan semua prinsip demokrasi dan administrasinya seperti halnya provinsi lain. Karena itu, tidak tepat jika Presiden tidak segera mengesahkan keistimewaan Yogyakarta.

Sementara mengenai konteks keistimewaan Joko Suryo menyatakan:

Mengenai konteks keistimewaan pada masa kemerdekaan, jelas tercantum dalam Amanat 5 September 1945 yang dikeluarkan HB IX dan Paku Alam (PA) VIII. Amanat itu menyatakan penggabungan diri Kesultanan Yogyakarta dan Kadipaten Pakualaman ke dalam NKRI

${ }^{2}$ Keterangan Pers mengenai RUU Keistimewaan Yogyakarta yang dibacakan pada tanggal Kamis, 2 Desember 2010.

${ }^{3}<$ http://indonesia-liek.blogspot.com/keistimewaan-yogyakarta-sejarah. htmll , diakses Senin 29 November 2010. 
dengan status daerah istimewa yang memiliki kekuasaan penuh untuk mengatur wilayahnya. Amanat itu dijawab Presiden Soekarno dengan menyerahkan Piagam Kedudukan kepada HB IX dan PA VIII sebagai tanda persetujuannya pada 6 September 1945 (tertanggal 19 Agustus 1945). Hal itu juga tercantum dalam Pasal 18 UUD 1945, sebelum perubahan, yang menyatakan, negara menghormati daerah yang memiliki status istimewa. ${ }^{4}$

Selanjutnya, Joko Suryo menilai, bahwa:

Dari sudut historis, sosiologis, dan politis, pemerintahan di bawah kepemimpinan sultan adalah sistem yang paling tepat bagi Yogyakarta, hal ini dengan suatu pertimbangan logis bahwa pemerintahan sultan menciptakan stabilitas bagi masyarakat Yogyakarta. Kalau sistem itu diganti, justru bisa menyebabkan instabilitas. ${ }^{5}$

Hal senada juga dinayatakan oleh Ketua Senat Akademik UGM Sutaryo yang mengatakan, bahwa tak bisa dimungkiri, ruh keistimewaan DIY adalah kepemimpinan sultan sebagai kepala daerah. Tanpa itu, keistimewaan tidak ada maknanya.

Berdasarkan beberapa pendapat tersebut, dapat disimpulkan bahwa keistimewaan dagi DIY adalah harga mati, dan begitupun kedudukan Sri Sultan dan Sri Paku Alam adalah ruh dan konsekuensi logis dari subtansi keistimewaan itu sendiri.

Untuk mengklarifikasi statemen 26 November 2010 sebagaimaa tersebut di atas, selanjutnya Presiden SBY mengadakan konferensi pers pada haris Kamis 2 Desember 2010. Salah satu statemennya adalah, bahwa: untuk kepimimpinan dan posisi gubernur DIY lima tahun mendatang yang terbaik dan yang paling tepat, tetap Sri Sultan Hamengkubuwono X". Pernyataan SBY inipun masih mengundang polemik, bagi masyarakat DIY, apabila statemen tersebut dicermati secara mendalam masih terdapat klausul yang mempertanyakan kembali sistem penetapan Sri Sultan Hamengkubuono dan Sri Paku Alam sebagai Gubenrnur dan wakil Gubernur DIY saat sekarang. Hal ini cukup dipahami dari pernyataan, bahwa "untuk lima tahun ke

\footnotetext{
${ }^{4}$ Ibid.

${ }^{5}$ Ibid.
} 
depan ...". Lalu bagaimana setelah lima tahun ...? Apakah sistem penetapan tersebut tidak berlaku lagi?

Dalam konteks pemerinah, pembahasan tentang Keistimewaan Yogyakarta, semata-mata tidak sekedar menyangkut pengisian jabatan Gubernur kepaa daerah, tetapi menyangkut subtansi dari keistimwaan iru sediri. $\mathrm{Hl}$ ini sebagai mana tertuang dalam usulan RUUK DIY. Tertapi subtansi yang menjadi perdebatan adalah mengenai mekanisme pengisian jabatan Gubenrnur Kepala Daerah yang menentukan, bahwa gubernur dan wakil gubernur DIY dipilih oleh DPRD atas persetujuan Sri Sultan Hamengku Buwono dan Sri Paku Alam. Lalu bagaimana dengan kedudukan Sri Sultan dan Sri Paku Alam? Dalam kondisi demikian kedudukan Sri Sultan dan Sri Paku Alam adalah sebagai Gubernur dan wakil Gubernur Utama. Jadi dalam draft ini menempatkan posisi Sri Sultan dan sri Paku Alam lebih tinggi dari pada Gubernur dan wakil Gubernur. Meski kedudukannya lebih tingi, tetapi dalam pemerintahan pada dasarnya keberadaan mereka tidak lebih dari sekedar simbolis kenegaraan, dan tidak memerankan diri secara aktif dalam permasalahan lalu lintas pemerintahan. Hal ini yang menjadi permasalahan dari sudut histories maupun yuridis.

Berdasarkan uraian tersebut senyataya baik secara historis maupun yuridis pembahasan Keistimewaan DIY telah menimbulkan polemik, sehingga isu hukum yang muncul adalah: (1) Bagaimanakah makna keistimewaan DIY dalam konteks NKRI? (2) Apakah mekanisme penetapan gubernur DIY inkonstitusional karena bertentangan dengan prinsip pemilihan secara demokratis sebagaimana ditentukan dalam Pasal 18A Ayat (4) UUD 1945?

Untuk memberikan elaborasi terhadap isu hokum tersebut, maka analisis dalam kajian ini tersusun atas: (1) Pendahuluan; (2) Makna Keistimewaan DIY dalam konteks NKRI; (3) Mekanisme Penetapan Gubernur DIY menurut Pasal 18A UUD 1945; (4) Penutup.

\section{Makna Keistimewaan Daerah Istimewa Yogyakarta (DIY) dalam Konteks Negara Kesatuan Republik Indonesia (NKRI)}

Pada bagian ini akan menganalisis isu pertama, yaitu bagaimanakah makna keistimewaan DIY dalam konteks NKRI? Sejak proklamasi kemerdekaan 17 Agustus 1945, UUD 1945 telah mengalami tiga kali keberlakuan, periode pertama 18 Agustus 1945 sampai dengan 19 Desember 1949, periode kedua, melalui dekrit presiden tanggal 5 juli 1959 sampai 19 Oktober 1999, dan periode ketiga 19 Oktober 1999 hingga sekarang. Pada masa pemberlakuan UUD 1945 ini, telah-diundangkan 
beberapa UU tentang Pemerintah Daerah yaitu, UU No. 1 Tahun 1945, UU No. 22 Tahun 1948, UU No. 18 Tahun 1965, UU No. 5 Tahun 1974, UU No. 22 Tahun 1999, dan terakhir UU No. 32 Tahun 2004.

Secara subtansi semua undang-undang pemerintah daerah tersebut pada dasarnya memberikan otonomi kepada daerah. Adapun pola otonomi daerah yang dianut sebagai berikut:

1. Otonomi seluas-luasnya kepada daerah dan sistem rumah tangga nyata, diatur dalam UU No. 11945 dan UU No. 22 Tahun 1948;

2. Otonomi nyata dan luas, diatur dalam Penpres No. 6 Tahun 1959 dan UU No. 18 Tahun 1965;

3. Otonomi nyata dan bertanggungjawab, diatur dalam UU No. 5 Tahun 1974;

4. Otonomi luas, nyata dan bertanggungjawab, diatur dalam UU No. 22 Tahun 1999 dan UU No. 32 Tahun 2004.

Dalam kerangka otonomi daerah tersebut, dalam NKRI juga mengadopsi keberadaan daerah istimewa maupun daerah khusus. Sebelum perubahan UUD 1945 atau sejak proklamasi kemerdekaan 17 Agustus 1945, setidaknya sudah ada 2 (dua daerah propinsi yang berstatus daerah istimewa dan satu daerah yang berstatus khusus. Ke dua daerah berstatus istimewa tersebut adalah Daerah Istimewa Aceh dan Daerah Istimewa Yogyakarta (DIY), sedangkan daerah khusus dimaksud adalah Daerah Khusus Ibukota (DKI) Jakarta. Yang menjadi pertanyaan adalah apakah yang menjadi dasar keistimewaan dan kekhususan daerah-daerah tersebut? Aceh disebut istimewa karena memang dalam sejarahnya didasarkan atas kompromi untuk mengadakan integrasi dengan KRI. Sebagaimana kita ketahui Aceh adalah satusatunya wilayah NKRI yang dahulunya tidak pernah mengalami penjajahan oleh bangsa Barat seperti Belanda, Portugis maupun Inggris. Oleh karena itu proses integrasi dengan NKRI berbeda dengan wilayah-wilayah daerah yang lain. Yogyajarta dinamakan istimewa karena latar belakang kesultanan sebagai bentuk pemerintahan keraton Yogyakarta, dan sudah ada sebelum NKRI lahir. Sedangkan Jakarta, dianggap daerah khusus karena sebagai ibukota negara diperlakukan sebagai daerah popinsi yang bersifat khusus, karena karakternya sebagai ibukota negara memang berbeda dari propinsi lainnya.

Selanjutnya, setelah perubahan UUD 1945 juga diadopsi adanya daerah khusus atau daerah istimewa. Pasal 18B ayat (1) UUD 1945 menentukan, "Negara mengakui dan menghormati satuan-satuan pemerintahan daerah yang bersifat khusus dan 
bersifat istimewa yang diatur dengan undang-undang". Menurut Jimly Asshidiqqie, ${ }^{6}$ dalam ketentuan tersebut terdapat lima hal yang pokok, yaitu: bahwa (1) negara mengakui; (2) negara menghormati; (3) yang diakui dan dihormati itu adalah sataunsatuan pemerintahan daerah; (4) satuan-satuan pemerintahan daerah dimaksud bersifat khusus atau istimewa; dan bahwa (5) satuan-satuan pemerintahan daerah yang bersifat khusus dan istimewa tersebut diatur dengan undang-undang. Apa yang dimaksud "negara mengakui"? Apakah pengakuan tersebut harus bersifat retrospektif, yaitu obyek yang diakui harus sudah ada lebih dulu dari pada pernyataan pengakuan, atau dapat juga bersifat proaktif dan "forward-lokking" di mana obyek yang diakui baru timbul setelah adanya pernyataan pengakuan.

Ketentuan Pasal 18B ayat (1) diadopsi ke dalam rumusan UUD 1945 pada Perubahan Kedua tahun 2000, artinya pernyataan pengakuan dalam Pasal 18B ayat (1) itu baru ada pada tanggal 18 Agustus 2000. Karena itu, timbul persoalan apakah satuan pemerintahan daerah khusus atau istimewa yang dimaksudkan yang harus diakui dan dihormati oleh negara itu hanya satuan-satuan pemerintahan daerah yang bersifat khusus atau istimewa yang ada sebelum tanggal 18 Agustus 2000 saja, atau dapat pula bentuk-bentuk satuan pemerintahan daerah yang baru. Terhadap permsalahan itu tentu dapat berkembang dua pendapat yang berbeda: Pertama, pendapat yang mennyatakan bahwa yang diakui dan dihormati hanya daerah yang sudah ada sebelumnya; dan Kedua, pendapat yang menyatakan, bahwa satuan-satuan pemerintahan daerah yang baru pun dapat memperolah status istimewa atau khusus. Masalah selanjutnya adalah ketika unit pemerintahan daerah yang dimaksud akan diberi status sebagai daerah istimewa atau daerah khusus, apakah Pasal 18B ayat (1) UUD 1945 dapat dijadikan dasar konstitusional untuk memutuskan hal itu? Jika bukan karena Pasal 18B ayat (1), apakah yang menjadi dasar sehingga pemerintahan daerah yang baru dapat diberikan status istimewa atau khusus, semisal Propinsi Papua yang berstatus daerah otonomi khusus setelah berlakunya Pasal 18B ayat (1)? Hal ini tentunya berbeda dengan status istimewa yang dimiliki oleh Aceh dan Yogyakarta. $^{7}$

Gagasan otonomi khusus Aceh dan Irian Jaya, bermula dari Majelis Permusyawaratan Rakyat Republik Indonesia (MPR-RI) yang mengamanatkan suatu

6 Jimly Asshiddiqqie, "Pokok-Pokok Hukum Tata Negara Indonesia Pasca Reformasi”, (Jakarta: Bhuana Ilmu Populer, tanpta tahun), hal. 484.

${ }^{7}$ Aceh sebelum amandemen UUD 1945 telah berstatus sebagai daerah istimewa dengan nama Daerah Istimewa Aceh, begitupun dengan Yogyakarta dengan nama Daerah Istimewa Yogyakarta (DIY). 
koreksi terhadap berbagai penyimpangan pelaksanaan ideologi Pancasila dan ketentuan UUD 1945. Wujud nyata dari amanat MPR-RI tersebut adalah pengaturan dan pembentukan otonomi khusus, sebagaimana termuat dalam Ketetapan MPR-RI No. IV/MPR/1999 tentang Garus-Garis besar Halauan Negara tahun 1999-2004, pada Bab IV huruf $G$ mengenai Pembangunan Daerah dalam angka 2 antara lain memuat kebijakan otonomi khusus bagi Aceh dan Irian Jaya. Dalam salah satu bagian dari Ketetapan MPR-RI No. IV/MPR/2000 tentang Rekomenasi Kebijakan dalam Penyelenggaraan Otonomi Daerah, Bagian III mengenai Rekomendasi, menyatakan:

... dalam rangka mengembangkan otonomi daerah dalam wadah Negara kesatuan Republik Indonesia, serta untuk menyelesaikan secara adil dan menyeluruh permasalahan di daerah yang memerlukan penanganan segera dan sungguh-sungguh, maka perlu ditempuh langkah-langkah sebagai berikut: (1) mempertahankan integrasi Aceh dengan menyelesaikan kasus Aceh secara berkeadilan dan bermartabat; (2) mempertahankan integrasi Irian jaya dengan menyelesaikan kasus pelanggaran HAM melalui proses peradilan yang jujur dan bermartabat.

Selanjutnya Ketetapan MPR-RI No. IV/MPR/2000 menetapkan:

... undang-undang Otonomi Khusus Daerah Istimewa Aceh dan Irian Jaya sesuai amanat Ketetapan Majelis Permusyawaratan Rakyat No. IV/MPR/1999 tentang Garis-Garis Besar Halauan Negara tahun 19992004, agar dikeluarkan selambat-lambatnya 1 Mei 2001 dengan memperhatikan aspirasi masyarakat daerah yang bersangkutan...

Ketetapan MPR-RI tersebut merupakan langkah penting dan mendasar peralihan praktek penyelenggaraan pemerintahan yang sentralistik kepada sistem desentralistik. Situasi penyelenggaraan pemerintahan negara yang tidak sesuai dengan Pancasilan dan UUD 1945, yang mendasari lahirnya Ketetapan MPR-RI tersebut, turut mengilhami lahirnya Pasal 18B UUD 1945 (Perubahan Kedua).

Atas dasar ketentuan tersebut, maka dibentuklah Undang-Undang Otonomi Khusus bagi Papua (yang sebelumnya bernama Irian Jaya) ${ }^{8}$ dan Undang-Undang

8 Provinsi Papua untuk pertama kali dibentuk berdasarkan Undang-Undang Nomor 1/Pnps/1962 tentang Pembentukan Provinsi Irian Barat Bentuk Baru serta Undang-Undang Nomor 12 Tahun 1969 tentang Pembentukan Provinsi Otonom Irian Barat dan Kabupaten-Kabupaten 
Otonomi Khusus Aceh (yang setelah menjadi daerah otonomi khusus berganti nama Nangroe Aceh Darussalam). ${ }^{9}$

Sekarang bagaiamana dengan Keistimewaan Daerah Istimewa Yogyakarta (DIY)? Untuk membahas keistimewaan DIY ini kita akan menganalisis dari dua sudut pandang yaitu historis dan yuridis.

\section{Analisis Historis Keistimewaan DIY}

Dari sudut historis Daerah Istimewa Yogyakarta (DIY) adalah provinsi tertua kedua di Indonesia setelah Jawa Timur, yang dibentuk oleh pemerintah negara bagian Indonesia. Provinsi ini juga memiliki status istimewa atau otonomi khusus. Status ini merupakan sebuah warisan dari zaman sebelum kemerdekaan. Kesultanan Yogyakarta dan juga Kadipaten Paku Alaman, sebagai cikal bakal atau asal usul DIY, memiliki status sebagai "Kerajaan vasal/Negara bagian/ Dependent state" dalam pemerintahan penjajahan mulai dari VOC, Hindia Perancis (Republik Bataav Belanda-Perancis), India Timur/EIC (Kerajaan Inggris), Hindia Belanda (Kerajaan Nederland), dan terakhir Tentara Angkatan Darat XVI Jepang (Kekaisaran Jepang). Oleh Belanda status tersebut disebut sebagai Zelfbestuurende Lanschappen dan oleh Jepang disebut dengan Koti/Kooti. Status ini membawa konsekuensi hukum dan politik berupa kewenangan untuk mengatur dan mengurus wilayah

Otonom di Provinsi Irian Barat, (LN Tahun 1969 Nomor 47, TLN Nomor 2907). Selanjutnya nama Provinsi Irian Barat digantikan menjadi Provinsi Irian Jaya berdasarkan Peraturan Pemerintah Nomor 5 Tahun 1973 (LN Tahun 1973 Nomor 9, TLN Nomor 2997). Kemudian berdasarkan aspirasi masyarakat Papua, nama Irian Jaya diganti menjadi Papua yang dituangkan dalam Keputusan Dewan Perwakilan Rakyat Provinsi Irian Jaya Nomor 7/DPRD/2000 tentang Pengembalian Nama Irian Jaya menjadi Papua. Atas dasar aspirasi tersebut, nama Papua secara resmi dipakai dalam UndangUndang Nomor 21 Tahun 2001 tentang Otonomi Khusus Bagi Provinsi Papua (Otsus Papua LNRI Tahun 2001 Nomor 135, TLN Nomor 4151).

${ }^{9}$ Kedudukan Daerah Istimewa Aceh (Provinsi Aceh) telah diberlakukan berdasarkan UU Nomor 44 Tahun 1999 tentang Penyelenggaraan Keistimewaan Provinsi Daerah Istimewa Aceh (LNRI Tahun 1999 Nomor 172, TLN Nomor 3893). Meski bersifat istimewa, secara praktis Aceh sejak kemerdekaan hingga reformasi, hanya bersifat formalistis, tidak subtantif apalagi terwujud dalam kenyataan. Hal ini yang mendorong disintegrasi, untuk itu pemerintah memformat kembali keberadaan Aceh sebagai daerah istimewa. Selanjutnya Daerah istimewa Aceh berstatus sebagai daerah otonomi khusus dan berganti nama menjadi Nangroe Aceh Darussalam (NAD) berdasarkan Undang-Undang Nomor 18 Tahun 2001 tentang Otonomi Khusus Bagi Daerah Istimewa Aceh sebagai Propinsi Nangroe Aceh Darussalam (LNRI Tahun 2001 Nomor 114, TLN 4134) yang selanjutnya dilengkapi dengan Undang-Undang Nomor 11 Tahun 2006 tentang Pemerintahan Aceh (LNRI Tahun 2006 Nomor 63, TLN Nomor 4634). 
[negaranya] sendiri di bawah pengawasan pemerintah penjajahan tentunya. Status ini pula yang kemudian juga diakui dan diberi payung hukum oleh Bapak Pendiri Bangsa Indonesia Soekarno yang duduk dalam BPUPKI dan PPKI sebagai sebuah daerah bukan lagi sebagai sebuah negara. ${ }^{10}$

Berdasarkan alasan tersebut, maka Daerah Istimewa Yogyakarta (DIY) memiliki sejarah yang khas dalam dirinya sendiri, yang sekaligus merupakan bagian dari sejarah survivalitas Indonesia sebagai sebuah bangsa dan negara. Kekhasan ini tidak dimiliki daerah lainnya, terutama dalam kaitannya dengan kelangsung hidup Indonesia sebagai sebuah bangsa dan negara. Kekhasan itu menyangkut bukan saja kontribusi DIY dalam mendirikan dan menjaga eksistensi NKRI, tapi juga secara simbolik dan aktual dalam mengisi visi keIndonesia-an secara lebih kongkret.

Penelaahan atas sejarah Yogyakarta dan Indonesia menunjukan, pertama, status keistimewaan Yogyakarta merupakan pilihan politik sadar yang diambil penguasa Yogyakarta, yakni Sultan HB IX dan Paku Alam VIII, dan bukan pemberian dari entitas politik nasional. Pilihan politik ini memiliki akar panjang yang melekat pada sejarah perjuangan rakyat Yogyakarta. Pelacakan secara diakronik yang dilakukan Djoko Suryo $(2007)^{11}$ menunjukkan, bahwa semangat perjuangan (fighting spirit) para pendiri kerajaan merupakan fondasi dari terbentuknya semangat juang kolektif (collective fighting spirit) dan heroismepatriotisme (heroism and patriotism spirit) masyarakat Yogyakarta dalam sejarah perjuangan bangsa. ${ }^{12} \mathrm{Hal}$-hal di atas telah menjadikan rakyat Yogyakarta sebagai aktor kolektif (collective historical actors) penggerak perlawanan terhadap kekuasaan Belanda dan revolusi kemerdekaan.

${ }^{10}$ Saafroedin Bahar et. al., ed., "Risalah Sidang BPUPKI-PPKI 29 Mei 1945-19 Agustus 1945”, Edisi kedua, (Jakarta: Sekretariat Negara RI, 1993).

11 Status keistimewaan Yogyakarta dimulai pasca Perang Jawa (1825-1830) dimana Kesultanan Yogyakarta dan Kesunanan Surakarta ditetapkan sebagai Vorstenlanden atau "Daerah Praja Kejawen". Lihat Djoko Suryo, Keistimewaan Sosial-Budaya Propinsi Daerah Istimewa Yogyakarta: Lampau, Kini dan Mendatang, Makalah, FGD Wacana Keistimewaan Yogyakarta dalam Kaca Mata Desentralisasi dan Good Governance, Yogyakarta, 6 Pebruari 2007. Lacak lebih jauh dalam Vincent Houben, "Keraton dan Kompeni: Surakarta dan Yogyakarta, 1830-1870", (Yogyakarta: Bentang Budaya, 2002). tahun).

${ }^{12}$ Lihat Wibatsu, "Prajurit Kraton Yogyakarta", (Yayasan Mandra Giri Mataram, tanpa 
Setelah proklamasi 17 Agustus 1945, raja dari Kesultanan dan Pakualaman Yogyakarta secara terpisah tetapi dengan format dan isi yang sama melalui Maklumat tanggal 5 September 1945 menyatakan integrasinya ke dalam Republik Indonesia dengan memilih status keistimewaan. Hal ini penting dipahami karena dari sisi keorganisasian keduanya memiliki struktur yang lengkap dan lebih siap untuk menjadi sebuah negara merdeka. ${ }^{13}$ Maklumat (Amanat) Sri Paduka Ingkeng Sinuwun Kangjeng Sultan dan Sri Paduka Kangjeng Gusti Pangeran Adipati Ario Paku Alam, secara tegas menyatakan, bahwa:

1) Negeri Ngajogjakarta Hadiningrat dan Negeri Paku-Alaman, adalah daerah istimewa dari Negara Republik Indonesia;

2) Sebagai Kepala Daerah, Sri Sultan dan Sri Paku Alam memegang segala kekuasaan dalam Negeri Ngajogjakarta Hadiningrat dan Negeri Paku-Alaman, selain itu juga meliputi segala urusan pemerintahan dan kekuasaan-kekuasaan lainnya;

3) Perberhubungan antara Negari Ngajogjakarta Hadiningrat dan PakuAlaman dengan Pemerintahan Pusat Negara Republik Indonesia bersifat langsung dan bertanggungjawab atas Negari lansung kepada Presiden. ${ }^{14}$

Satu hal yang perlu diketahui, bahwa keputusan politik di atas diambil di tengah-tengah tawaran penguasa Belanda memberikan kekuasaan atas seluruh Jawa bagi HB IX yang ditolak beliau. ${ }^{15} \mathrm{Hal}$ ini tentunya menunjukkan kearafian Sri Sultan dan Sri Paku Alam sebagai seorang negarawan sejati yang jauh dari sifat ambisi politik.

${ }^{13}$ Tim Jurusan Ilmu Pemerintahan Fisipol UGM, 2007, “Draft Naskah Akademik Rancangan Undang-Undang Keistimewaan Provinsi Daerah Istimewa Yogyakarta”, (Yogyakarta: Jurusan Ilmu Pemerintahan (JIP) FISIPOL UGM Dengan Partnership For Governance Reform Indonesia, 2007), hal. 8 .

${ }^{14}$ Sujamto, "Daerah Istimewa Dalam Negara Kesatuan Republik Indonesia", (Jakarta: Bina Aksara, 1988), hal. 297-298.

${ }^{15}$ Berulangkali Belanda mengirim utusan menemui HB IX untuk kepentingan ini. Tercatat misalnya, Residen E. M. Stok, Berkhuis, Kol. van Langen, Prof. Husein Jayaningrat dan Sultan Hamid yang dijadikan utusan. Tetapi tidak satupun yang dapat bertemu langsung dengan Sultan HB IX yang selalu mengutus salah seorang saudaranya, Pangeran Prabuningrat, Pangeran Mudaningrat atau Pangeran Bintara untuk menemui para utusan. Alasan yang selalu disampaikan adalah kesehatan beliau yang tidak mengijinkan. 
Dari sudut Kesultanan dan Pakualaman, penolakan di atas, boleh jadi tidak sepenuhnya bersifat altruistik bagi kepentingan penegakan Indonesia merdeka. Keputusan di atas juga, seperti disampaikan Ichlasul Amal, ${ }^{16}$ boleh jadi lebih menggambarkan pilihan keduanya sebagai tokoh pergerakan nasional, bukan sebagai penguasa Kesultanan dan Pakualaman. Tetapi dari sudut masyarakat Yogyakarta, fakta bahwa semangat juang dalam mempertahankan hidup (survival spirit) dan kelangsung (sustainability spirit) dari Indonesia sebagai sebuah bangsa dan negara adalah realitas sejarah yang telah diterima luas. Karenanya, pilihan Sultan HB IX dan PA VIII di atas tetap harus dibaca sebagai bentuk penghormatan dari penguasa dan rakyat Yogyakarta atas Indonesia dengan implikasi yang luar biasa bagi eksistensi Indonesia. Karenanya, dari sudut pandang pemerintah nasional, penetapan pemerintah RI yang mengakui keistimewaan Yogyakarta melalui UU No. 3 Tahun 1950 tentang Pembentukan Daerah Istimewa Yogyakarta harus dibaca lebih sebagai penghormatan terhadap ketulusan dan komitmen Yogyakarta berintegrasi dengan Indonesia ketimbang pemberian keistimewaan oleh otoritas politik nasional. Saling menghargai secara timbal-balik inilah yang menjadi pembeda penting posisi kesejarahan Yogyakarta dalam kaitannya dengan NKRI yang tidak dimiliki oleh daerah-daerah lain, termasuk bentuk-bentuk Kesultanan dan kerajaan yang ada di berbagai daerah pada masa awal kemerdekaan Indonesia.

Kedua, Yogyakarta memberikan ruang wilayah dan penduduk yang kongkrit bagi Indonesia awal. Pengakuan kedua raja atas kedaulatan Indonesia di wilayah kekuasaannya telah mengisi ruang kosong dan rakyat sebagai dua unsur kunci sebuah negara yang bernama Republik Indonesia. Proklamasi 17 Agustus 1945, tidak secara otomatis memberikan ruang dan rakyat yang kongkrit bagi Indonesia merdeka. Penundukan diri pada kedaulatan otoritas NKRI yang dipilih kedua kerajaanlah yang memberikan makna kongkrit bagi pernyataan kemerdekaan oleh Bung Karno dan Bung Hatta.

Secara teoritik, unsur berdirinya negara adalah rakyat atau penduduk, wilayah, pemerintah, dan kedaulatan (Rodee, et. Als, 1976). Setelah Proklamasi dideklarasikan, lingkup wilayah dan rakyat yang masuk dalam Republik Indonesia masih kabur. Pengumuman lingkup wilayah dan rakyat yang disepakati oleh BPUPKI pada sidang tanggal 19 Agustus 1945 adalah lebih pada klaim normatif dari pada kondisi faktual. Melalui Maklumat tanggal 5 September 1945 Hamengkubuwono IX dan Paku Alam VIII, menjadikan

\footnotetext{
${ }^{16}$ Ichlasul Amal dalam Tim Jurusan Ilmu Pemerintahan Fisipol UGM, Op. Cit.
} 
unsur-unsur terbentuknya negara menjadi kongkret dan lengkap. Dengan Maklumat ini, wilayah dan rakyat yang berada di kedua kerajaan tersebut secara otomatis menjadi wilayah dan rakyat dari RI yang baru dideklarasikan yang memiliki status istimewa pula. Kedua kerajaan ini bahkan ikut menanggung pembiayaan pemerintahan antara tahun 1946 dan $1947 .{ }^{17}$

Lebih dari sekadar memberikan ruang dan rakyat yang kongkrit bagi Indonesia awal, rakyat Yogyakarta yang menjadi rakyat kongkrit Indonesia merdeka adalah rakyat yang memiliki kehendak (will) untuk hidup sebagai sebuah bangsa. Sejarah perjuangan rakyat Yogyakarta sebagaimana diungkapkan dalam berbagai dokumen dan diperkuat oleh hasil FGD, forum Ahli dan forum Panel Ahli yang dilakukan TIM JIP memastikan hal ini. Realitas sejarah inilah yang menyebabkan Yogyakarta mendapatkan penghormatan sebagai Kota Revolusi dan Kota Perjuangan antara tahun 1945 1949. ${ }^{18}$

Ketiga, Yogyakarta menjadi kekuatan penyelamat ketika Indonesia berada dalam situasi krisis untuk mempertahankan Proklamasi Kemerdekaan 17 Agustus 1945. Dijadikannya DIY sebagai Ibukota negara ketika Jakarta tidak dapat dipertahankan sebagai ibu kota negara sebagai akibat agresi militer Belanda ke-1 tahun 1948 dan fakta bahwa Yogyakarta menjadi satu dari tiga daerah yang tetapmenjadi NKRI ketika daerah lain terpecah menjadi Republik Indonesia Serikatsudah menjadi pemahaman umum. Demikian pula fakta bahwa peristiwaSerangan Umum 1 Maret 1949 yang menyebabkan eksistensi RI tetap diakuidunia Internasional setelah sebelumnya dikabarkan dikuasai Belanda mengambil tempat di Yogyakarta dengan Sultan HB IX sebagai figur kunci. $^{19}$

Tetapi peran yang sama penting yang jarang diperbincangkan adalah peran pemersatu DIY bagi Indonesia. Pada tingkat simbolik, peran tersebut dijalankan melalui pematahan mitos ketidak-mungkinan penyatuan entitas politik yang berseberangan akibat politik devide at empera yang diterapkan penjajah Belanda yang telah dimulai sejak periode singkat kolonialisme Inggris

${ }^{17}$ Josef Riwu Kaho, Masukan yang disampaikan dalam forum Panel Ahli, 11 Mei 2007.

${ }^{18}$ Djoko Suryo, Op. Cit.

19 SESKOAD, Serangan UMUM 1 Maret 1949 di Yogyakarta, "Latar Belakang dan Pengaruhnya", (Seskoad, 1989), bandingkan dengan Chidmad, Tatag, Sri Endang Sumiyati dan Budi Hartono, "Pelurusan Sejarah Serangan Oemoem 1 Maret 1949", (Tanpa kota: Media Presindo, 2001). 
di bawah Raffles ${ }^{20} 16$ yang memunculkan dua entitas politik di Yogyakarta, yakni Kesultanan dan Pakualaman. Keputusan politik HB IX dan PA VIII untuk keluar sebagai satu kesatuan politik di bawah NKRI - yang dijadikan dasar oleh Tim JIP dalam merumuskan keduanya sebagai satu kesatuan politik dalam RUU tentang Keistimewaan Yogyakarta ini -- memberikan pesan simbolik yang sangat kuat bahwa Indonesia yang bersatu adalah mungkin. Hal ini memiliki dua fungsi, yakni mematahkan mitos kedigdayaan politik pecahbelah kolonial dan memberikan optimisme kepada wilayah lainnya tentang keabsahan gagasan dan praktek persatuan Indonesia. Hal ini, menopang eksistensi Indonesia berikutnya. Keempat, pada tingkat yang lebih kongkrit, fungsi pemersatu atau perekat bangsa DIY dilakukan pasca kemerdekaan. Melalui pendirian Universitas Gadjah Mada (UGM), nasionalisme dan identitas ke-Indonesia-an dilahirkan, dipelihara, dimekarkan hingga menemukan bentuk jadinya. UGM yang didirikan pada 19 Desember 1949 bukan semata-mata pusat pendidikan tinggi, tapi menjalankan fungsi sebagai locus dan titik temu anak bangsa dari penjuru Indonesia sehingga ia menjadi miniatur Indonesia. Di Yogyakarta sekat-sekat kedaerahan dikikis dan dibangun ide tentang ke-Indonesia-an secara lebih luas. Dari Yogyakartalah, ke- Indonesia-an merambah pasti ke berbagai daerah. Eksistensi UGM tidak mungkin terwujud apabila tidak ada visi tentang ke-Indonesia-an dan kebesaran jiwa dari penguasa Yogyakarta kala itu, yakni Hamengkubuwono IX.

Visi ke-Indonesia-an Sri Sultan Hamengku Buwono IX yang diikuti oleh kesediaannya memfasilitasi kehadiran UGM, juga dapat dibaca sebagai pengorbanan Sri Sultan HB IX. Hal ini bukan saja tercermin dari kerelaan beliau menyediakan bagian sakral di Keraton yaitu Siti Hinggil dan Pagelaran menjadi salah satu bangunan awal UGM termasuk beberapa ruangan di Keraton; juga tidak terbatas pada kesediaan Sultan HB IX memberikan tanahnya di daerah Bulaksumur sebagai pusat dan tempat berdirinya UGM hingga saat sekarang; ataupun pada keteguhan beliau mempertahankan keberadaan UGM di Yogyakarta setelah Ibukota Negara dikembalikan ke

\footnotetext{
${ }^{20}$ Terbelahnya Kesultanan Yogyakarta dan Kadipaten Pakualaman dimulai pada era Raffless, Hal ini disampaikan P. J. Suwarno dalam diskusi Pemetaan Pemikiran, 14 Maret 2007. Lihat juga P. J. Suwarno, Keistimewaan Daerah Istimewa Yogyakarta, Makalah dipresentasikan pada diskusi mengenai Keistimewaan Yogyakarta yang diselenggarakan Universitas Atmadjaya, Yogyakarta, 2 Juni 2007; P. J. Suwarno, "Hamengku Buwono IX dan Sistem Birokrasi Pemerintahan Yogyakarta 1942-1974”, (Yogyakarta: Kanisius, 1994).
} 
Jakarta. $^{21}$ Tetapi juga pada perubahan perilaku beliau sebagaimana dikisahkan kembali oleh kerabat keraton. ${ }^{22}$

Peran strategis Kesultanan sebagai kekuatan pemersatu disempurnakan oleh peran yang sama yang dijalankan masyarakat Yogyakarta. ${ }^{23}$ Sejak awal, warga Yogyakarta telah berfungsi sebagai "induk semang" bagi para mahasiswa dan aktivis pergerakan dari berbagai daerah. Peran masyarakat ini sedemikian strategisnya terutama dalam mengintegrasikan warga dari berbagai daerah di Indonesia ke dalam satu kesatuan identitas dan pemahaman baru dengan ke-Indonesia-an sebagai titik simpulnya. Lewat masyarakat Yogya, kesadaran mengenai dan keharusan untuk hidup dalam kebhinekaan Indonesia terbentuk di antara para mahasiswa dan aktivis pergerakan nasional dari berbagai daerah.

Fakta-fakta sejarah di atas membuktikan bahwa sejarah DIY adalah sejarah yang diabdikan untuk menjamin eksistensi dan keberlangsungan Indonesia, sejarah yang diabdikan untuk merawat ke-Indonesia-an.

\section{Analisis Yuridis Keistimewaan DIY}

Sebagaimana telah dipaparkan pada bagain di atas, bahwa berbeda dengan NAD dan Papua, Daerah Istimewa Yogyakarta sejak perubahan UUD 1945 (sejak berlakunya Pasal 18B ayat (1) UUD 1945) belum memiliki UU yang mengatur ketentuan khusus sebagaimana NAD dan Papua. Meski demikian subtansi keistimewaan bagi Daerah Istimewa Yogyakarta "secara tradisional" dapat dilihat dalam ketentuan, antara lain: (1). Kontrak politik antara Nagari Kasultanan Yogyakarta \& Kadipaten Puro Pakualaman dengan Pemimpin Besar Revolusi Soekarno sebagaimana dituangkan dalam Pidato Penobatan HB

${ }^{21}$ Interpretasi pada bagian di atas diilhami presentasi Bambang Purwanto, sejarawan dari UGM yang disampaikan dalam forum diskusi Pemetaan Pemikiran Tim JIP dengan para ahli untuk mendapatkan input bagi penyusunan naskah akademik, 14 Maret 2007.

${ }^{22}$ Pada saat Sultan HB IX merelakan Siti Hinggil dan Pagelaran dan ruang-ruang lainnya sebagai lokasi awal UGM, Sultan harus berjalan memutar untuk masuk ke dalam rumahnya agar tidak melewati Siti Hingil dan Pagelaran. Kedua ruangan ini berada di posisi paling depan kraton Ngayogyakarta Hadiningrat. Informasi ini berdasarkan penuturan GBPH Prabukusumo, adik Sultan HB X, pada panel Forum Ahli untuk pemetaan pemikiran, 14 Maret 2007 di Hotel Jayakarta.

${ }^{23}$ Bagian ini diilhami oleh pertanyaan P. M. Laksono, Tadjuddin Nur Effendi, dan sejumlah aktivis NGO tentang tempat rakyat dalam keistimewaan Yogyakarta yang disampaikan dalam forum Pemetaan Pemikiran dan Forum Panel Ahli yang diselenggarakan JIP Fisipol UGM. 
IX, 18 Maret 1940; (2) Piagam Kedudukan Sri Sultan Hamengku Buwono IX \& Sri Paduka Pakualam VIII tanggal 19 Agustus 1945; (3) Amanat 5 September 1945; Amanat 30 Oktober 1945; (4) Amanat Proklamasi Kemerdekaan NKRI-DIY, 30 Mei 1949; dan (5) Amanat Tahta Untuk Rakyat, 1986. Dipihak lain secara yuridis formal, kedudukan DIY telah diakui dalam UUD 1945 sebelum amandemen melalui Penjelasan Pasal 18 UUD 1945 dan ditegaskan kembali dalam Pasal 8b ayat (1) dan (2) UUD NKRI 1945 setelah amandmeen.

Namun secara khusus keistimewaan DIY diatur tersendiri dalam Pasal 2 UU No. 3 tahun 1950 yang kemudian diubah dengan UU No. 19/1950; selain itu juga UU No. 22/1948, UU No. 1/1957, UU No. 18/1965; dan saat ini, keistimewaan tersebut juga diatur dalam Pasal 226 ayat (2) UU No 32/2004 yang merujuk pada Pasal 122 UU No 22/1999 (berikut penjelasannya) yang juga merujuk pada Pasal 91 sub b UU No 5/1974.

Berdasarkan dasar-dasar hukum tersebut, jelaslah bahwa secara geneologis predikat keistimewaan Yogyakarta di tataran defacto dan yuridis formal, dapat dirujuk pada beberapa atura hukum tersebut, selain juga amanat Sri Paduka Ingkeng Sinuwun Kanjeng Sultan dan Amanat Sri Paduka Kanjeng Gusti Pangeran Adipati Ario Paku Alam. Kedua amanat tersebut dapat dipreskripsikan sebagai novum hukum yang menyatakan bahwa status Yogyakarta, dalam ranah yuridis formal, telah mengalami perubahan dari sebuah daerah Zelfbesturende Landschappen atau daerah Swapraja menjadi sebuah daerah yang bersifat istimewa di dalam teritorial Negara Kesatuan Republik Indonesia. Secara lebih generik, keistimewaan Yogyakarta memiliki akar yang kuat dalam konstitusi. Pasal 18 B ayat (1) Undangundang Dasar 1945 menegaskan, "Negara mengakui dan menghormati satuansatuan pemerintah daerah yang bersifat khusus atau istimewa yang diatur dengan undang-undang." Penegasan yang lebih gamblang lagi dapat kita telusuri dalam Konstitusi RIS tahun $1949^{24}$ dan UUDS tahun $19500^{25}$

\footnotetext{
${ }^{24}$ Bagian III tentang Daerah Swapraja, Pasal 64 Konstitusi RIS 1949 menegaskan pengakuan atas swapraja yang sudah ada. Sementara Pasal 65 menegaskan, "(M)engatur kedudukan daerahdaerah swapraja masuk dalam tugas kekuasaan daerah-daerah bagian yang bersangkutan dengan pengertian bahwa mengatur itu dilakukan dengan kontrak yang diadakan antara daerah-daerah bagian dan daerah-daerah swapraja bersangkutan dan bahwa dalam kontrak itu, kedudukan istimewa swapraja akan diperhatikan dan bahwa tiada satupun dari daerah-daerah swapraja yang sudah ada dapat dihapus atau diperkecil bertentangan dengan kehendaknya, kecuali untuk kepentingan umum dan sesudah undang-undang Federasi yang dinyatakan, bahwa kepentingan umum
} 
Seperti telah dinyatakan di depan, bahwa pada tingkat yang lebih operasional, keistimewaan Yogyakarta diatur melalui Undang-Undang Nomor 3 Tahun 1950 tentang Pembentukan Daerah Istimewa Yogyakarta (BN 1950 No. 48). Hanya saja, dalam UU ini tidak diatur secara jelas dan menyeluruh substansi dan ragam urusan yang secara spesifik merefleksikan keistimewaan Yogyakarta. ${ }^{26}$ Tiga belas urusan yang ditetapkan melalui UU No. 3 Tahun 1950 setara dengan urusan yang dimiliki daerah lain sesuai dengan Pasal 23 dan Pasal 24 Undang-undang Nomor 22 Tahun $1948 .^{27}$

Dibandingkan dengan daerah-daerah lain, UU ini mewajibkan Yogyakarta tetap harus menjalankan urusan-urusan rumah tangga dan kewajiban-kewajiban lain yang telah ditetapkan sebelum pembentukan UU No. 3 Tahun 1950. Selain

menuntut penghapusan atau pengecilan itu, memberi kuasa untuk itu kepada Pemerintah Daerah Bagian yang bersangkutan".

${ }^{25}$ Sementara UUDS 1950 memberikan pengaturan yang lebih detail dalam Bab IV tentang Pemerintah Daerah dan Daerah-daerah Swapraja yang meliputi 6 ayat yang disebarkan dalam 2 Pasal, yakni Pasal 131 dan 132. Pasal 132 ayat (2) menegaskan, "Daerah-daerah swapraja yang ada tidak dapat dihapus atau diperkecil bertentangan dengan kehendaknya, kecuali untuk kepentingan umum dan sesudah Undang-undang yang menyatakan bahwa kepentingan umum menuntut pengahapusan atau pengecilan itu, memberi kuasa untuk itu kepada Pemerintah".

${ }^{26}$ UU 3/1950 tentang Pembentukan Daerah Istimewa Yogyakarta sangatlah singkat (hanya 7 pasal dan sebuah lampiran daftar kewenangan otonomi). UU tersebut hanya mengatur wilayah dan ibu kota, jumlah anggota DPRD, macam kewenangan, serta aturan-aturan yang sifatnya adalah peralihan. UU 19/1950 sendiri adalah perubahan dari UU 3/1950 yang berisi penambahan kewenangan bagi DIY. Status keistimewaan Yogyakarta tidak diatur lagi dalam UU pembentukan karena telah diatur dalam UU 22/1948. Dalam UU 3/1950 disebutkan secara tegas Yogyakarta adalah sebuah Daerah Istimewa setingkat Popinsi B U K A N sebuah Propinsi Walaupun nomenklaturnya mirip, namun saat itu mengandung konsekuensi hukum dan politik yang amat berbeda terutama dalam hal kepala daerah dan wakil kepala daerahnya (lihat UU 22/1948 di atas). Walau begitu DIY bukan pula sebuah monarki konstitusional

${ }^{27}$ Catatan yang disampaikan oleh Josef Riwu Kaho dalam Forum Panel Ahli, 11 Mei 2007 menegaskan, UU No. 22 Tahun 1948 tidak mengenal urusan pangkal karena menggunakan ajaran rumah tangga materiel (materiele hoishouding begrip). Urusan pangkal hanya dikenal dalam ajaran rumah tanggal formal (formale huishouding begrip) yang baru digunakan dalam UU No. 1 Tahun 1957 dengan prinsip otonomi riil dan seluas-luasnya. Urusan-urusan yang diberikan kepada DIY dalam UU ini meliputi urusan umum; urusan pemerintahan umum; urusan agraria; urusan pengairan, jalan-jalan dan gedung-gedung; urusan pertanian dan perikanan; urusan kehewanan; urusan kerajinan, perdagangan dalam negeri, perindustrian dan koperasi; urusan perburuhan dan sosial; urusan pengumpulan bahan makanan dan pembagiannya; urusan penerangan; urusan pendidikan, pengajaran dan kebudayaan; urusan kesehatan; dan urusan perusahaan. 
itu, juga disebutkan bahwa pemerintah Yogyakarta harus memikul semua hutang-piutang yang terjadi sebelum pembentukan Daerah Istimewa Yogyakarta. ${ }^{28}$ Lima bulan setelah ditetapkan, Pemerintah melakukan perubahan atas UU No. 3 Tahun 1950, melalui UU No. 19 Tahun 1950 (BN 1950 No. 48) yang ditetapkan pada tanggal 14 Agustus $1950 .{ }^{29}$ Perubahan dilakukan pada Pasal 4 ayat (1) mengenai urusan yang wajib dilaksanakan yang diekspansi menjadi 15 urusan disertai sejumlah perubahan nomenklatur. ${ }^{30}$

Berbagai produk hukum yang mengatur tentang pemerintahan daerah di Indonesia pasca UU No 22/1948, yaitu: UU No 1 Tahun 1957, Perpres 6 Tahun 1959 (disempurnakan), Perpres 5 Tahun 1960 (disempurnakan), UU No 18 Tahun 1965, UU No 5 Tahun 1974, UU No 22 Tahun 1999 dan UU No 32 Tahun 2004 tetap memberikan pengakuan kuat mengenai status keistimewaan Yogyakarta, walaupun secara format pengaturan pemerintahan daerahnya sama dengan daerah-daerah lain.

Dalam UU No 1/1957, keberadaan Daerah-daerah yang bersifat istimewa mempunyai posisi yang kuat. Pengakuan atas daerah-daerah yang bersifat istimewa dituangkan dalam pasal 1 ayat (1), (2), dan (3). Dalam pasal 1 ayat (1) ditegaskan, "( $\mathrm{Y})$ ang dimaksud dengan Daerah dalam Undang-undang ini ialah daerah yang berhak mengurus rumah tangganya sendiri, yang disebut juga "Daerah Swatantra" dan "Daerah Istimewa". Meskipun pasal dan ayatayat ini tidak secara spesifik menyebutkan nama daerah-daerah yang menyandang status istimewa, kesimpulan sederhana yang bisa diambil dari pengaturan di atas adalah bahwa posisi Yogyakarta sebagai sebuah daerah istimewa tetap berlaku sesuai UU No 3 Tahun 1950. UU ini bahkan secara spesifik mengatur status kepala daerah istimewa sebagaimana tergambar dalam

${ }^{28}$ The Liang Gie dalam Tim Jurusan Ilmu Pemerintahan Fisipol UGM, dalam "Draft naskah Akademik Rancangan Undang-Undang Keistimewaan Provinsi Daerah Istimewa Yogyakarta", $O p$. Cit.

${ }^{29}$ UU No. 19 Tahun 1950 diberlakukan mulai 15 Agustus 1950 dengan PP No. 31 Tahun 1950 (BN 1950 No. 58).

${ }^{30} 15$ urusan yang diserahkan pada Pemerintah Daerah Istimewa Yogyakarta melalui UU No. 19 tahun 1950 meliputi urusan umum; urusan pemerintahan umum; urusan agraria; urusan pengairan, jalan-jalan dan gedung-gedung; urusan pertanian, perikanan dan koperasi; urusan kehewanan; urusan kerajinan, perdagangan dalam negeri dan perindustrian; urusan perburuhan; urusan sosial; urusan pembagian (distribusi); urusan penerangan; urusan pendidikan, pengajaran dan kebudayaan; urusan kesehatan; urusan lalu lintas dan angkutan bermotor; dan urusan perusahaan. 
pasal 25 dan pasal 27 tentang Kepala Daerah Istimewa dan Wakil Kepala Daerah Istimewa, pasal 29 tentang Kedudukan Keuangan Kepala Daerah Istimewa dan Wakil Kepala Daerah Istimewa, pasal 30 tentang Sumpah/janji Kepala Daerah Istimewa dan Wakil Kepala Daerah Istimewa, dan pasal 73 ayat (1) Peraturan Peralihan. Pasal-pasal tersebut, merupakan dasar yuridis penting yang dapat dirujuk dalam mengatur substansi keistimewaan. Berdasarkan pemahaman di atas, Soejamto (1988: 37-39) merinci subtansi keistimewaan dari daerah-daerah yang menyandang status keistimewaan, termasuk Provinsi Daerah Istimewa Yogyakarta sebagai berikut:

1) Berlainan dengan Kepala Daerah biasa, Kepala Daerah Istimewa diangkat oleh Pemerintah Pusat dari keturunan keluarga yang berkuasa di Daerah itu pada masa sebelum Republik Indonesia dan yang masih menguasai daerahnya, dengan memperhatikan syaratsyarat kecakapan, kejujuran, kesetiaan serta adat-istiadat dalam daerah tersebut.

2) Oleh karena itu, Kepala Daerah Istimewa tidak dapat ditumbangkan oleh DPRD

3) Mengenai gaji dan segala penghasilan yang sah yang melekat pada jabatan Kepala Daerah Istimewa tersebut ditetapkan oleh Pemerintah Pusat, bukan oleh Daerah itu sendiri.

Peneguhan secara legal formal keberadaan suatu daerah yang bersifat istimewa tidak melemah seiring dengan terjadinya perubahan politik di aras nasional. Dekrit Presiden 5 Juli 1959 yang mengembalikan kedudukan UUD 1945 sebagai konstitusi tertinggi di Indonesia, tetap memberikan ruang pengakuan yang luas bagi keistimewaan suatu daerah. Hal ini dapat dilihat dalam Penpres No 6 Tahun 1959 (disempurnakan), khususnya dalam pasal 3, pasal 6, pasal 7 dan pasal 8 ayat (1), yang substansinya sama dengan UU 1/1957. UU No 18 Tahun 1965 yang dihasilkan kembali mempertegas pengakuan atas keberadaan daerah-daerah yang sifatnya istimewa sebagaimana dirumuskan dalam pasal 88 ayat (1). UU ini bahkan secara spesifik mengatur substansi dari keistimewaan Yogyakarta sebagaimana dapat dirujuk dalam Pasal 88 ayat (2), sebagai berikut:

(a) Sifat istimewa sesuatu Daerah yang berdasarkan atas ketentuan mengingat kedudukan dan hak-hak asal-usul dalam pasal 18 Undang-undang Dasar yang masih diakui dan berlaku hingga sekarang atau sebutan Daerah Istimewa atas alasan lain, berlaku terus hingga dihapuskan. 
(b) Kepala Daerah dan Wakil Kepala Daerah Istimewa Yogyakarta yang sekarang, pada saat mulai berlakunya Undang-undang ini, adalah Kepala Daerah dan Wakil Kepala Daerah Propinsi Daerah Istimewa Yogyakarta, yang tidak terikat pada jangka waktu masa jabatan dimaksud pada pasal 17 ayat (1) dan pasal 21 ayat (5).

.Penelusuran kembali berbagai regulasi yang menyangkut pemerintah daerah di atas menegaskan, hingga tahun 1965, status keistimewaan suatu daerah, dan secara lebih spesifik substansi keistimewaan diletakkan pada kedudukan Kepala Daerah dan Wakil Kepala Daerah yang menjabat pada waktu itu. Hal-hal di luarnya yang terkait dengan jalannya roda pemerintahan secara umum tidak diatur secara khusus. Dengan kata lain, selain daripada kedudukan khusus kepala daerah, pengaturan selebihnya mengenai Daerah yang menyandang status istimewa tidak berbeda dengan daerah-daerah lain di Indonesia. Hal inilah yang membawa kami pada kesimpulan adanya kekaburan makna keistimewaan Yogyakarta yang perlu mendapat pengaturan sekarang ini.

Pola yang sama terus berlanjut pada periode politik baru yang sama sekali berbeda. UU No 5 Tahun 1974, sekalipun dilahirkan dalam konteks sentralisasi pemerintahan yang sangat kuat, setelah melalui perdebatan yang cukup panjang di DPR, ${ }^{31}$ tetap mengakui Yogyakarta sebagai Daerah Istimewa. Sebagaimana pengaturan sebelumnya, ciri pokok keistimewaan tetap diletakan pada keunikan posisi Kepala Daerah dan Wakil Kepala Daerah dimana masa jabatan, syarat dan cara pengangkatan Kepala Daerah dan Wakil Kepala Daerah tidak tunduk pada kaidah-kaidah regulasi yang berlaku bagi daerahdaerah lain (Soejamto, ibid: 87).

Perubahan politik nasional berikutnya yang terjadi setelah turunnya Soeharto tidak mengakhiri pengakuan legal atas keberadaan daerah yang bersifat istimewa. Pasal 122 Undang-undang Nomor 22 Tahun 1999 secara literal mempertegas status keistimewaan Daerah Istimewa Yogyakarta dan Aceh melalui penegasan:

Keistimewaan untuk Propinsi Daerah Istimewa Aceh dan Propinsi Daerah Istimewa Yogyakarta, sebagaimana dimaksud dalam Undang-Undang Nomor 5 Tahun 1974, adalah tetap dengan

${ }^{31}$ Perdebatan mengenai status istimewa bagi Yogyakarta dan Aceh muncul karena kuatnya semangat penyeragaman. format pengaturan daerah-daerah di Indonesia pada waktu itu. Detail perdebatan dapat dilihat dalam, antara lain, Soejamto, 1988: Bab VI. 
ketentuan bahwa penyelenggaraan pemerintahan Propinsi Istimewa Aceh dan Propinsi Istimewa Yogyakarta didasarkan pada undangundang ini.

Secara lebih spesifik penjelasan Pasal 122 menegaskan:

Pengakuan keistimewaan Propinsi Istimewa Yogyakarta didasarkan pada asal-usul dan peranannya dalam sejarah perjuangan nasional, sedangkan isi keistimewaannya adalah pengangkatan Gubernur dengan mempertimbangkan calon dari keturunan Sultan Yogyakarta dan Wakil Gubernur dengan mempertimbangkan calon dari keturunan Paku Alam yang memenuhi syarat sesuai dengan undangundang ini.

Berdasarkan ketentuan-ketentuan tersebut, subtsansi Istimewa bagi Daerah Istimewa Yogyakarta terdiri dari 3 (tiga) unsur: Pertama, Istimewa dalam hal Sejarah Pembentukan Pemerintahan Daerah Istimewa, sebagaimana diatur UUD 45, Pasal 18 dan Penjelasannya mengenai hak asal-usul suatu daerah dalam teritoir Negara Indonesia terdapat lebih kurang 250 zelfbestuurendelandschappen \& volks-gemeenschappen serta bukti-bukti authentik/fakta sejarah dalam proses perjuangan kemerdekaan, baik sebelum maupun sesudah Proklamasi Kemerdekaan 17 Agustus 1945 hingga sekarang ini dalam memajukan Pendidikan Nasional \& Kebudayaan Indonesia; Kedua, Istimewa dalam hal Bentuk Pemerintahan Daerah Istimewa Yogyakarta yang terdiri dari penggabungan dua wilayah Kasultanan dan Pakualaman menjadi satu daerah setingkat provinsi yang bersifat kerajaan dalam satu kesatuan wilayah Negara Kesatuan Republik Indonesia (sebagaimana disebutkan dalam Amanat 30 Oktober 1945, 5 Oktober 1945 \& UU No.3/1950); Ketiga, Istimewa dalam hal Kepala Pemerintahan Daerah Istimewa Yogyakarta yang dijabat oleh Sultan \& Adipati yang bertahta (sebagaimana amanat Piagam Kedudukan 19 Agustus 1945 yang ditulis secara lengkap nama, gelar, kedudukan seorang Sultan \& Adipati yang bertahta sesuai dengan angka urutan bertahtanya).

Undang-Undang paling akhir yang mengatur mengenai Pemerintahan Daerah, yakni UU Nomor 32 Tahun 2004 juga memberi ruang afirmasi bagi predikat keistimewaan sejumlah daerah. Hal ini dituangkan dalam Pasal 2 ayat (8) yang menyatakan: Negara mengakui dan menghormati satuan-satuan pemerintahan daerah yang bersifat khusus atau bersifat istimewa yang diatur dengan undang-undang.

Jika dicermati secara seksama, rentang waktu antara tahun. 1950 hingga tahun 2004 yang mencakup masa berlaku UU No 3 Tahun 1950 hingga UU 
Nomor 32 Tahun 2004, maka dua kesimpulan umum dapat diambil. Pertama, adanya konsistensi pada level yuridis yang mengakui keberadaan suatu daerah yang bersifat istimewa. Jika produk perundang-undangan dipahami sebagai buah dari proses politik, maka hal di atas sekaligus menggambarkan adanya pengakuan dan penerimaan politik yang terus berlanjut mengenai status keistimewaan suatu daerah dalam kerangka NKRI. Yogyakarta, termasuk dalam hal ini. Kedua, konsistensi pengakuan atas status keistimewaan sebuah daerah, tidak diikuti oleh pengaturan yang bersifat komprehensif mengenai substansi keistimewaan sebuah daerah. Hal inilah yang pada tataran operasional melahirkan simpul-simpul penafsiran yang bersifat multiinterpretatif dengan segala konsekwensinya. Perkembangan Yogyakarta sejak tahun 1998 yang ditandai oleh ketidak-pastian hukum dan politik yang terus berulang, terutama menjelang momentum perubahan kepemimpinan lokal mengungkapkan dengan jelas implikasi yang ditimbulkan oleh keragaman interpretasi sebagai akibat dari kekaburan regulasi. Karena alasan-alasan inilah, kehadiran sebuah undang-undang tentang keistimewaan Yogyakarta yang komprehensif sangat diperlukan guna memberikan jaminan hukum bagi pelaksanaan pemerintahan di Yogyakarta.

Berdasarkan paparan diatas dapat disimpulkan, bahwa satu hal yang tidak dapat ditawar lagi adalah, bahwa DIY memiliki legitimasi yang kuat sebagai daerah istimewa dalam kerangka Negara Kesatuan Republik Indonesia. Keisitimewaan tersebut tidak dapat diganggugugat baik oleh kekuasaan ekssekutif maupun legislatif, karena secara yuridis formal telah diamanatkan dalam konstitusi (UUD 1945) sebagai kekuasaan tertinggi sebagai pelaksana kedaulatan rakyat.

\section{Mekanisme Penetapan Gubernur DIY Menurut Pasal 18 Ayat (4) UUD 1945}

Bagian ini hendak menganalisis isu ke dua, yaitu apakah mekanisme penetapan Gubernur DIY bertentangan dengan Pasal 18 Ayat (4) UUD 1945? Merujuk pada beberapa ketentuan perundang-undangan yang menjadi dasar hukum keistimewaan DIY, maka berkaitan dengan mekanisme pengisian jabatan kepala daerah terdapat beberapa aturan yang memberikan landasan.

UU No. 22 tahun 1948 merupakan UU kedua yang mengatur tentang UU Pokok Pemerintahan Daerah. UU ini menggantikan UU No. 1 tahun 1945 yang dari segi materi terlalu sederhana, sehingga dalam pelaksanaannya timbul banyak 
kesulitan. Dalam UU tersebut diatur susunan dan kedudukan Daerah Istimewa baik dalam diktum maupun penjelasannya. Berkaitan dengan pengisisn jabatan Kepala Daerah diatur dalam Pasal 18 ayat (5) dan (6), bahwa:

Ayat (5)

Kepala Daerah Istimewa diangkat oleh Presiden dari keturunan keluarga yang berkuasa di daerah itu di zaman sebelum Republik Indonesia dan yang masih menguasai daerahnya, dengan syarat-syarat kecakapan, kejujuran dan kesetiaan, dan dengan mengingat adat istiadat di daerah itu.

Ayat (6)

Untuk Daerah Istimewa dapat diangkat seorang Wakil Kepala Daerah Istimewa dengan mengingat syarat-syarat tersebut dalam ayat (5). Wakil Kepala Daerah Istimewa adalah anggota Dewan Pemerintah Daerah.

Selanjutnya Penjelasan umum UU No 22/1948 sub 29 dan 30, menyatakan:

Tentang dasar pemerintahan di daerah istimewa adalah tidak berbeda dengan pemerintahan di daerah biasa; kekuasaan ada ditangan rakyat (Dewan Perwakilan Rakyat Daerah). Yang berbeda ialah tentang angkatan Kepala Daerahnya. Juga yang mengenai angkatan Wakil Kepala Daerah, jikalau ada dua daerah istimewa dibentuk menjadi satu menurut Undang-undang Pokok ini, maka perlulah diadakan Wakil Kepala Daerah dari keturunan Raja dari salah satu daerah yang digabungkan tadi. Tingkatan daerah istimewa sama dengan tingkatan daerah biasa. Hasil penyelidikan itu akan menentukan apakah Daerah Istimewa itu masuk tingkat Provinsi, Kabupaten, atau Desa. Djikalau masuk tingkatan Kabupaten, maka Daerah Istimewa ini masuk ke dalam lingkungan Provinsi biasa.

Ketentuan mengenai pengisian jabatan Gubernur Kepala Daerah Istimewa selanjutnya ditentukan dalam UU No 1 tahun 1957 yang menggantikan UU No. 22/1948. Pasal 25 ayat (1), (2), dan (3), menetapkan bahwa: 
Ayat (1)

Kepala Daerah Istimewa diangkat dari calon yang diajukan oleh DPRD dari keturunan keluarga yang berkuasa di zaman sebelum Republik Indonesia dan yang masih mengusai daerahnya, dengan memperhatikan syarat-syarat kecakapan, kejujuran, kesetiaan serta adat istiadat dalam daerah itu, dan diangkat dan diberhentikan oleh: a. Presiden bagi Daerah Istimewa tingkat $I$.

Ayat (2)

Untuk Daerah Istimewa dapat diangkat calon yang diajukan oleh DPRD, seorang Wakil Kepala Daerah Istimewa yang diangkat dan diberhentikan oleh penguasa yang mengangkat/memberhentikan Kepala Daerah Istimewa, dengan memperhatikan syarat-syarat tersebut dalam ayat (1).

Ayat (3)

Kepala dan Wakil Kepala Daerah Istimewa karena jabatannya adalah berturut-turut menjadi Ketua serta anggota dan Wakil Ketua serta anggota Dewan Pemerintah Daerah.

Ketentuan mengenai pengisian jabatan Gunernur dan Wakil Gubernur Kepala Daerah melalui mekanisme penetapan (pengangkatan) ini tetap dipertahankan pada beberapa peraturan tentang Pemerintahan Daerah, bahkan pada suatu waktu jabatan tersebut tidak terikat oleh waktu (seumur hidup). Peraturan-peraturan terebut seperti antara lain PenPres No $6 / 1959,{ }^{32}$ UU No. $18 / 1965,{ }^{33}$ UU No. $5 / 1970,{ }^{34}$ UU No. $22 / 1999^{35}$ maupun UU No. 32 tahun $2004 .^{36}$

32 Pasal 6 ayat (1) dan (2) PenPres No 6/1959, menetapkan: (1) Kepala Daerah Istimewa diangkat dari keturunan keluarga yang berkuasa menjalankan pemerintahan daerah itu di zaman sebelum Republik Indonesia dan yang masih berkuasa menjalankan pemerintahan di daerahnya, dengan memperhatikan syarat-syarat kecakapan, kejujuran, kesetiaan pada Pemerintah Republik Indonesia serta adat istiadat dalam daerah itu dan diangkat dan diberhentikan oleh Presiden. (2) Untuk Daerah Istimewa dapat diadakan seorang Wakil Kepala Daerah Istimewa, yang diangkat dan diberhentikan dengan memperhatikan syarat-syarat tersebut dalam ayat (1) pasal ini. 
Berdasarkan ketentuan peraturan perundang-undangan yang menjadi landasan hukum keistimewaan DIY, khususnya mekanisme pengisian jabatan Gubernur pada dasarnya kesumuanya mengikuti mekanisme penetapan (pengangkatan), terkecuali ketentuan dalam UU No. 32 tahun 2004 yang tidak secara eksplisit menyatakan tetapi tetap mengisyaratkan sistem penetapan.

Satu prinsip penting dalam rangka otonomi daerah, adalah bahwa melalui pelaksanaan otonomi daerah, peranan kepala daerah diharapkan mampu memahami perubahan yang terjadi secara cepat dan tepat dalam perspektif nasional maupun internasional. Keberhasilan untuk menyesuaikan perubahan akan sangat ditentukan oleh kepala daerah (Gubernur, Bupati, dan walikota) sejauh mana dapat mengembangkan visi dan misi organisasi. ${ }^{37}$

Philipus M. Hadjon, ${ }^{38}$ mengatakan:

${ }^{33}$ Sifat istimewa suatu daerah berlaku terus hingga dihapuskan. Kepala Daerah dan Wakil Kepala Daerah Istimewa Yogyakarta yang sekarang, pada saat berlakunya UU ini, adalah Kepala Daerah dan Wakil Kepala Daerah Provinsi Daerah Istimewa Yogyakarta, yang tidak terikat pada jangka waktu masa jabatan dimaksud dalam Pasal 17 ayat (1) dan Pasal 21 ayat (5). Lihat Pasal 88 ayat (2) sub a dan b UU No $18 / 1965$

${ }^{34}$ Pada saat berlakunya UU ini: Kepala Daerah dan Wakil Kepala Daerah Istimewa Yogyakarta yang sekarang adalah Kepala Daerah dan Wakil Kepala Daerah menurut UU ini dengan sebutan Kepala Daerah Daerah Istimewa Yogyakarta dan Wakil Kepala Daerah Istimewa Yogyakarta, yang tidak terikat pada ketentuan masa jabatan, syarat, dan cara pengangkatan bagi Kepala Daerah dan Wakil Kepala Daerah lainnya. Lihat Pasal 91 sub b UU No 5/1974

${ }^{35}$ Pengakuan keistimewaan Provinsi Istimewa Yogyakarta didasarkan pada asal-usul dan peranannya dalam sejarah perjuangan nasional, sedangkan isi keistimewaanya adalah pengangkatan Gubernur dengan mempertimbangkan calon dari keturunan Sultan Yogyakarta dan Wakil Gubernur dengan mempertimbangkan calon dari keturunan Paku Alam yang memenuhi syarat sesuai UU ini. Lihat Penjelasan Pasal 122 UU No 22/1999

${ }^{36}$ Pasal 226 ayat (1) dan (2) UU No 32/2004, menetapkan bahwa: (1) Ketentuan dalam UU ini berlaku bagi Provinsi Daerah Khusus Ibukota Jakarta, Provinsi Nanggroe Aceh Darussalam, Provinsi Papua, dan Provinsi Daerah Istimewa Yogyakarata sepanjang tidak diataur secara khusus dalam UU tersendiri. (2) Keistimewaan untuk Provinsi Daerah Istimewa Yogyakarta sebagaimana dimaksud dalam UU Nomor 22 Tahun 1999, adalah tetap dengan ketentuan bahwa penyelenggaraan pemerintahan Provinsi Daerah Istimewa Yogyakarta didasarkan pada UU ini.

${ }^{37}$ Konsideran penjelasan UU No. 12 Tahun 2003 tentang Pemilu Legislatif, hal. 61.

38 Philipus M. Hadjon, "Pengantar Hukum Administrasi Indonesia", (Yogyakarta: Gadjah Mada University Press, 1993), hal.113-114. 
Kepala Daerah dan Wakil Kepala Daerah mempunyai dua fungsi pokok. Pertama, sebagai Kepala Derah Otonom. Kedua, sebagai pimpinan yang menyelenggarakan urusan pemerintahan umum yang menjadi wakil pemerintah pusat di Daerah. Sebagai Kepada Daerah Otonom disebut Kepala Daerah, yaitu Kepala Pemerintah daerah Provinsi, Kepala daerah Kabupaten, dan Kepala Daerah Kota. Sebagai pimpinan penyelenggaraan pemerintahan umum di daerah disebut Kepala Wilayah dengan penamaan menurut jenjang wilayah masing-masing, Kepala Wilayah Provinsi adalah Gubernur, Kepala Kabupaten adalah Bupati, Kepala Pemerintahan Kota adalah wali Kota.

Berdasarkan pendapat tersebut, maka Kepala daerah dan wakil kepala daerah mempunyai peran yang sangat strategis dalam rangka pengembangan kehidupan demokrasi, keadilan, pemerataan, kesejahteraan masyarakat, memelihara hubungan serasi antara pemerintah psat dan daeah serta antar-daerah untuk menjaga keutuhan Negara Kesatuan Republik Indonesia. Oleh sebab itu, diperlukan figur Kepala Daerah yang mampu mengembangkan inovasi, berwasan ke depan dan siap melakukan perubahan ke arah yang lebih baik. Konsekuensi logis dari ketentuan tersebut adalah bahwa pemilihan Kepala Daerah dan Wakil Kepala Daerah harus dilaksanakan secara demokratis, artinya keberadaan Kepala Daerah dan Wakil Kepala Daerah harus memperoleh legitimasi masyarakat secara penuh. Di sisi lain pemilihan kepala daerah secara demokratis tersebut sebagai manifestasi daripada wujud kedaulatan rakyat pada tingkat daerah yaitu provinsi, kabupaten dan atau kota dalam kerangka NKRI.

Amandemen Undang-Undang Dasar Negara republik Indonesia Tahun 1945 telah meletakkan dasar-dasar kehidupan berbangsa dan bernegara dengan meletakkan kedaulatan berada di tangan rakyat yang diwujudkan melalui pengembangan format politik dalam negeri dan pengembangan sistem pemerintahan termasuk sistem penyelenggaraan pemerintahan daerah ke arah yang lebih demokratris, salah satunya adalah mekanisme pemilihan kepala daerah.

Berdasarkan ketentuan Pasal 18 ayat 4 UUD 1945 menentukan: "Gubernur, Bupati, dan walikota masing-masing sebagai kepala pemerintah daerah propinsi, kabupaten, dan kota dipilih secara demokratis".

Pada tingkat konstitusi, Undang-Undang Dasar 1945 tidak memberikan pejelasan bagaimakah yang dimaksud dengan pemilihan demokratis tersebut? Tetapi dalam konteks akademik dan undang-undang memandang bahwa pemilihan Kepala Daerah dan Wakil Kepala Daerah secara demokratis dapat dilakukan melalui dua 
cara, pertama; pemilihan dilakukan oleh DPRD, ${ }^{39}$ kedua; pemilihan secara langsung oleh rakyat.

Dalam rangka pengisian jabatan Kepala Daerah dan Wakil Kepala Daerah, kecuali UU No. 32 Tahun 2004, dilakukan oleh DPRD melalui pemilihan secara bersama. Tetapi dengan mengingat Pasal 62 e Undang-Undang Nomor 22 Tahun 2003 tentang Tentang Susunan dan Kedudukan MPR, DPR, DPD, dan DPRD, bahwa UU ini tidak lagi mencantumkan tugas dan wewenang DPRD untuk memilih Kepala Daerah dan Wakil Kepala Daerah. Dengan demikian, makna pemilihan kepala daerah secara demokratris sebagaimana dimaksud dalam UUD 1945 dapat ditafsirklan sebagai pemilihan secara langsung oleh rakyat. ${ }^{40}$

Sementara Philipus M. Hadjon berpendapat:

Prinsip demokrasi yang terkandung dalam Pasal 18 (ayat 3 dan 4) menyangkut pemilihan anggota DPRD dan Kepala Daerah secara langsung ... dengan demikian dalam sistem ketatanegaraan Republik Indonesia, pemilihan umum tidak hanya untuk memilih wakil rakyat (DPR, DPD, DPRD) tetapi juga untuk Kepala Pemerintahan. ${ }^{41}$

Meski demikian, yang menjadi pertanyaan adalah benarkah makna demokratis dalam konteks Pasal 18 Ayat (4) UUD 1945, semata-mata hanya bermakna pemilihan secara langsung oleh rakyat? DPR yang diwakili Patrialis Akbar dan Lukman Hakim Saifuddin dalam keterangan tertulis tertanggal 14 Februari 2005 pada sidang Mahkamah Konstitusi untuk putusan perkara gugatan judicial review UU No. 32 Tahun 2004 terhadap UUD 1945 mengatakan:

Lahirnya kata demokratis yang dicantum dalam Pasal 18 ayat (4) UUD RI Tahun 1945 ketika itu menjelang perubahan kedua tahun 2000.

${ }^{39} \mathrm{Hal}$ ini mengandung makna bahwa walaupun pemilihan kepala daerah dilakukan melalui DPRD tetapi mengakomodasi prinsip-prinsip demokrasi atau dilakukan secara demokrasi, maka tata cara pemilihan demikian disebut pemilihan yang demokratis.

${ }^{40}$ Lihat Titik Triwulan Tutik, "Konstruksi Hukum Tata Negara Indonesia Pasca amandemen UUD 1945", (Jakarta: Prenada Media Group, 2010), hal. 270.

41 Philipus M. Hadjon, Kedudukan Undang-Undang Pemerintah Daerah dalam Sistem Pemerintahan Pasca Amandemen UUD 1945, makalah, Seminar Sistem Pemerintahan Indonesia Pasca Amandemen UUD 1945, diselenggarakan BPHN Depkimham bekerjasama dengan FH Unair dan Kanwil Depkimham Prov. Jatim, Surabaya 9-10 Juni 2004, hal. 4. 
Setidak-tidaknya dikarenakan adanya 2 (dua) pendapat yang berbeda mengenai cara pemilihan Kepala Daerah. Satu pendapat menghendaki pemilihan kepala daerah dilakukan secara langsung oleh rakyat dan sepenuhnya mengikuti apa yang terjadi pada pemilihan presiden dan wakil presiden sementara pendapat yang lain menghendaki tidak dilakukan secara langsung. ${ }^{42}$

Pertimbangan hukum Mahkamah Konstitusi selanjutnya mengatakan:

Rumusan "dipilih secara demokratis" dalam ketentuan pilkada juga mempertimbangkan pelaksanaan pemilihan kepala daerah di daerahdaerah yang bersifat khusus dan istimewa sebagaimana dimaksudkan Pasal 18B ayat (1) UUD 1945 .... Tetapi hal ini tidak dapat diartikan bahwa pilkada secara langsung menjadi satu-satunya cara untuk memaknai frasa "dipilih secara demokratis" yang dimuat dalam Pasal 18 ayat (4) UUD 1945 ... Namun kenyataannya dalam menjabarkan maksud "dipilih secara demokratis" dalam Pasal 18 ayat (4) UUD 1945 pembuat undang-undang telah memilih cara pilkada secara langsung. Sebagai konsekuensinya asas-asas dan lembaga penyelenggara pemilu harus tercermin dalam penyelenggaraan pilkada". 43

Selanjutnya MK juga mengatakan:

Kalimat demokratis tersebut tidak serta merta berarti dipilih langsung oleh rakyat, tetapi dapat pula pemilihan dilakukan oleh DPRD pun berarti demokrasi apabila pelaksanaanya memang dilakukan secara demokratis tanpa ada intervensi dan menipulasi. Tafsir demokratis dalam Pasal 18 ayat (4) UUD 1945 sebagai "pemilihan langsung oleh rakyat" berdasarkan UU Susduk MPR, DPR, DPD, dan DPRD yang mengatakan bahwa DPRD tidak memiliki kewenangan lagi untuk memilih Kepala Daerah dan Wakil Kepala Daerah. ${ }^{44}$

${ }^{42}$ Putusan Mahkamah Konstitusi No. 072-073/PUU-II/2004 Pengujian Undang-Undang No. 32 Tahun 2004 Tentang Pemerintah Daerah Terhadap UUD 1945, hal. 61

${ }^{43}$ Ibid., hal. 108-109 
Sesui dengan Konsideran Penjelasan Umum angka 2 Pemerintah Daerah UU No. 32 Tahun 2004 Tentang Pemerintah Daerah menyatakan:

\begin{abstract}
"Pemilihan secara demokratis terhadap Kepala Daerah tersebut, dengan mengingat bahwa tugas dan wewenang DPRD menurut Undang-Undang Nomor 22 Tahun 2003 tentang Susunan dan Kedudukan Majelis Permusyawaratan Rakyat, Dewan Perwakilan Rakyat, Dewan Perwakilan Daerah, dan Dewan Perwakilan Rakyat Daerah, menyatakan antara lain bahwa DPRD tidak memiliki tugas dan wewenang untuk memilih Kepala Daerah dan Wakil Kepala Daerah, maka pemilihan secara demokratis dalam Undang-Undang ini dilakukan oleh rakyat secara langsung".
\end{abstract}

Selanjutnya menurut Taufiqqurahman Syahuri, ${ }^{45}$ bahwa:

Makna kata demokratis yang tercantum di dalam Pasal 18 ayat (4) UUD 1945 ditafsirkan oleh Mahkamah Konstitusi sebagaimana disebut dalam Pasal 59 ayat (1) dan (2) tanpa penjelasan.

Berdasaerkan beberapa pendapat tersebut, jelaslah bahwa dalam konteks pengisian jabatan kepala daerah melalui pemilihan demokratis menurut Pasal 18 ayat (4) UUD 1945, tidak semata-mata dilakukan secara langsung oleh rakyat maupun pemilihan yang dilakukan oleh DPRD, tetapi juga mempertimbangkan pelaksanaan pemilihan kepala daerah di daerah-daerah yang bersifat khusus dan istimewa sebagaimana dimaksudkan Pasal 18B ayat (1) UUD 1945. Artinya, bahwa terdapat mekanisme (tata cara) lain dalam proses pengisian jabatan kepala daerah, seperti halnya sistem penetapan Gubernur Kepala Daerah dan Wakil Gubernur Propinsi DIY. Hal ini dengan pertimbangan, bahwa karakter dan kebutuhan masing-masing daerah berbeda sebagaimana telah ditetapkan dalam Pasal 18 UUD 1945. Dengan demikian sistem penetapan Hamengku Buwono X dan Sri Pakualam, sebagai Gubernur dan Wakil Gubernur DIY tidaklah bertentang dengan konstitusi (tidak inkonstitusional) selama penetapan tersebut memperoleh legitimasi dari masyarakat (masyarakat menghendakinya).

${ }^{44}$ Ibid., hal. 109.

${ }^{45}$ Taufiqqurahman Syahuri, Anatomi Putusan MKRI Tentang Pilkada, Makalah, Seminar Putusan Mahkamah Konstitusi Pengujian UU No. 32 Tahun 2004 Tentang Pemerintåh Daerah, Kerja sama Puslitka MK, Hans Seidel Foundation, dan PS-HTN-FH-UI, Jakarta, 28 Maret 2005, hal. 6. 


\section{Simpulan}

Dalam kerangka NKRI, diadopsi kedudukan daerah khusu dan daerah istimewa sebagai entitas dari kesatuan genekologis yang memiliki sifat karakter yang berbeda dengan daerah lainnya.

Daerah Istimewa Yogyakarta, baik secara historis maupun yuridis memiliki legitimasi yang kuat sebagai daerah istimewa. Keistimewaan tersebut tercermin bik daru sudut histors maupun yuridis. Secara historis, Pertama, status keistimewaan Yogyakarta merupakan pilihan politik sadar yang diambil penguasa Yogyakarta, yakni Sultan HB IX dan Paku Alam VIII, dan bukan pemberian dari entitas politik nasional. Kedua, Yogyakarta memberikan ruang wilayah dan penduduk yang kongkrit bagi Indonesia awal. Ketiga, Yogyakarta menjadi kekuatan penyelamat ketika Indonesia berada dalam situasi krisis untuk mempertahankan Proklamasi Kemerdekaan 17 Agustus 1945. Sedangkan secara yuridis yaitu Pertama, adanya konsistensi pada level yuridis yang mengakui keberadaan suatu daerah yang bersifat istimewa. Kedua, konsistensi pengakuan atas status keistimewaan sebuah daerah, tidak diikuti oleh pengaturan yang bersifat komprehensif mengenai substansi keistimewaan sebuah daerah.

Keistimwaan DIY juga tercermin dalam mekanisme pengisian jabatan guernur Kepada daerah dan Wakil Gubernur, dengan sistem pengangkatan/penetapan Sri Sultan dan Sri Pakualam. Secara konstitusional sistem penetapan Hamengku Buwono X dan Sri Pakualam, sebagai Gubernur dan Wakil Gubernur DIY tidaklah bertentang dengan konstitusi (tidak inkonstitusional) selama penetapan tersebut memperoleh legitimasi dari masyarakat (masyarakat menghendakinya). 


\section{Daftar Pustaka}

\section{Buku}

Bahar, Saafroedin., et. al., (eds.) Risalah Sidang BPUPKI-PPKI 29 Mei 194519 Agustus 1945, Edisi kedua, Jakarta: Sekretariat Negara RI, 1993.

Bratakusumah, Deddy Supriady dan Solihin, Dadang. Otonomi Penyelenggaraan Pemerintah Daerah, Jakarta: Gramedia Pustaka Utama, 2002

Chidmad, Tatag, Sri Endang Sumiyati dan Budi Hartono. Pelurusan Sejarah Serangan Oemoem 1 Maret 1949, Media Presindo 2001.

Hadjon, Philipus M. Pengantar Hukum Administrasi Indonesia, Yogyakarta: Gadjah Mada University Press, 1993. - et. al., Pengantar Hukum Administrasi Indonesia: Introduction to Indonesian Administrative Law, Yogyakarta: Gajah Mada University Press, 2002.

Harsono. Hukum Tata Negara: Pemerintahan Lokal dari Masa ke Masa, Yogyakarta: Liberty, 1992.

Houben, Vincent. Keraton dan Kompeni: Surakarta dan Yogyakarta, 18301870, Yogyakarta: Bentang Budaya, 2002.

Jimly Asshiddiqqie. Pokok-Pokok Hukum Tata Negara Indonesia Pasca Reformasi, Jakarta: Bhuana Ilmu Populer, 2009.

SESKOAD. Serangan UMUM 1 Maret 1949 di Yogyakarta, Latar Belakang dan Pengaruhnya. Seskoad, 1989.

Sujamto. Daerah Istimewa Dalam Negara Kesatuan Republik Indonesia, Jakarta: Bina Aksara, 1988.

Suwarno, P. J. Hamengku Buwono IX dan Sistem Birokrasi Pemerintahan Yogyakarta 1942-1974, Yogyakarta: Kanisius, 1994.

Tim Jurusan Ilmu Pemerintahan Fisipol UGM. Draft Naskah Akademik Rancangan Undang-Undang Keistimewaan Provinsi Daerah Istimewa Yogyakarta, Yogyakarta: Jurusan Ilmu Pemerintahan (JIP) FISIPOL UGM Dengan Partnership For Governance Reform Indonesia 2007. 
Tutik, Titik Triwulan. Konstruksi Hukum Tata Negara Indonesia Pasca Amandemen UUD 1945, Jakarta: Prenada Media Group, 2010.

Wibatsu. Tth. Prajurit Kraton Yogyakarta, Mataram: Yayasan Mandra Giri Mataram, tanpa tahun.

\section{Makalah}

Hadjon, Philipus M. "Sistem Pembagian Kekuasaan Negara (Analisis Hukum Tata Negara)", Makalah disampaikan pada Seminar Hukum di FH Unair, 2004.

. "Kedudukan Undang-Undang Pemerintah Daerah dalam Sistem Pemerintahan Pasca Amandemen UUD 1945", Makalah, Seminar Sistem Pemerintahan Indonesia Pasca Amandemen UUD 1945, diselenggarakan BPHN Depkimham bekerjasama dengan FH Unair dan Kanwil Depkimham Prov. Jatim, Surabaya 9-10 Juni 2004.

Purwanto, Bambang. "Pemetaan Pemikiran Tim JIP dengan Para Ahli Untuk Mendapatkan Input Bagi Penyusunan Naskah Akademik", Makalah disampaikan dalam forum diskusi, 14 Maret 2007.

Suwarno, P. J. "Keistimewaan Daerah Istimewa Yogyakarta", Makalah dipresentasikan pada diskusi mengenai Keistimewaan Yogyakarta yang diselenggarakan Universitas Atmadjaya, Yogyakarta, 2 Juni 2007.

Suryo, Djoko. "Keistimewaan Sosial-Budaya Propinsi Daerah Istimewa Yogyakarta: Lampau, Kini dan Mendatang”, Makalah, FGD Wacana Keistimewaan Yogyakarta dalam Kaca Mata Desentralisasi dan Good Governance, Yogyakarta, 6 Pebruari 2007.

Syahuri, Taufiqqurahman. "Anatomi Putusan MKRI Tentang Pilkada, Makalah, Seminar Putusan Mahkamah Konstitusi Pengujian UU No. 32 Tahun 2004 Tentang Pemerintah Daerah, Kerja sama Puslitka MK, Hans Seidel Foundation, dan PS-HTN-FH-UI, Jakarta, 28 Maret 2005.

\section{Internet}

$<$ http://indonesia-liek.blogspot.com/keistimewaan-yogyakarta-sejarah.html $>$, diakses Senin 29 November 2010 
Keterangan Pers mengenai RUU Keistimewaan Yogyakarta yang dibacakan pada tanggal Kamis, <http://www.presidensby.info/index.php/statik/ KeteranganPersmengenaiRUUKeistimewaanYogyakarta.html>, diakses tanggal 27 November 2010.

\section{Peraturan Perundang-Undangan}

Undang-Undang Dasar 1945 sebelum amandmen.

Undang-Undang Dasar 1945 setelah amandemen.

Konstitusi Republik Indonesia Serikat 1949.

Undang-Undanag Dasar Sementera 1950.

Undang-Undang Nomor 22 Tahun 1948 tentang Pokok-Pokok Pemerintahan Daerah.

Undang-Undang Nomor 3 tahun 1950 tentang Daerah Istimewa Yogyakarta.

Undang-Undang Nomor 19 tahun 1950 tentang Daerah Istimewa Yogyakarta.

Undang-Undang Nomor 1 Tahun 1957 tentang Pokok-Pokok Pemerintahan Daerah (LNRI Tahun 1957 Nomor 1143).

Undang-Undang Nomor 1/Pnps/1962 tentang Pembentukan Provinsi Irian Barat.

Undang-Undang Nomor 12 Tahun 1969 tentang Pembentukan Provinsi Otonom Irian Barat dan Kabupaten-Kabupaten Otonom di Provinsi Irian Barat, (LNRI Tahun 1969 Nomor 47, TLN Nomor 2907).

Undang-Undang Nomor 5 Tahun 1974 tentang Pemerintah Daerah (LNRI 1974 Nomor 38; TLN 3037).

Undang-Undang Nomor 22 Tahun 1999 tentang Pemerintahan Daerah (LNRI 1999 Nomor 60; TLN 3839).

Undang-Undang Nomor 44 Tahun 1999 tentang Penyelenggaraan Keistimewaan Provinsi Daerah Istimewa Aceh (LNRI Tahun 1999 Nomor 172, TLN Nomor 3893).

Undang-Undang Nomor 18 Tahun 2001 tentang Otonomi Khusus Bagi Daerah Istimewa Aceh sebagai Propinsi Nangroe Aceh Darussalam (LNRI Tahun 2001 Nomor 114, TLN 4134). 
Undang-Undang Nomor 21 Tahun 2001 tentang Otonomi Khusus Bagi Provinsi Papua (Otsus Papua LNRI Tahun 2001 Nomor 135, TLN Nomor 4151).

Undang-Undang Nomor 12 Tahun 2003 tentang Pemilu Legislatif.

Undang-Undang Nomor 32 Tahun 2004 tentang Pemerintahan Daerah.

Undang-Undang Nomor 11 Tahun 2006 tentang Pemerintahan Aceh (LNRI Tahun 2006 Nomor 63, TLN Nomor 4634).

Putusan Mahkamah Konstitusi No. 072-073/PUU-II/2004 Pengujian UndangUndang No. 32 Tahun 2004 Tentang Pemerintah Daerah Terhadap UUD 1945.

Peraturan Pemerintah Nomor 5 Tahun 1973 (LN Tahun 1973 Nomor 9, TLN Nomor 2997).

Keputusan Dewan Perwakilan Rakyat Provinsi Irian Jaya Nomor 7/DPRD/ 2000 tentang Pengembalian Nama Irian Jaya menjadi Papua. 